\title{
Autologous antibodies to human bladder cancer*
}

\author{
H. Barton Grossman, Gary Wedemeyer, and Judith Stein \\ Department of Surgery, Section of Urology, University of Michigan Medical Center, Ann Arbor, MI 48109, USA
}

Summary. The autologous serologic reactivity of 13 patients with bladder cancer was evaluated using cell lines derived from each individual's own tumor as targets. Protein $\mathrm{A}$ and immune adherence assays were employed to determine antibody binding to the tumor targets at varying passage numbers. Autologous reactivity was found in 6 of the 13 cell lines tested. However, the titer was usually low regardless of the passage number. Seven autologous serum/cell line combinations were tested using both low and high passage cells as targets. In six of these combinations, the degree of antibody binding was similar with both low and high passage target cells. The incidence of autologous reactivity in the 12 patients with urothelial tumors was $50 \%$.

\section{Introduction}

The basis for immunotherapy rests in the belief that tumorassociated antigens can be defined that are different from those expressed on normal tissues. Prior to the modern era of murine and human monoclonal antibodies, tumor-associated antigens were defined using polyclonal human sera in cellular and serologic assays [2, 9, 21]. These efforts strongly suggested that tumor-associated antigens do exist, and that in some cases the antigens are highly tumor-restricted [22]. Evidence for such conclusions were found in melanoma, leukemia, renal cancer, and other tumors [3, 8 , $20,27]$. The application of monoclonal antibody technology (primarily murine) has confirmed much of this early data. Monoclonal antibodies have been defined which preferentially bind to a variety of tumors including melanoma, leukemia, and carcinomas of the bladder, breast, kidney, and lung $[1,6,7,18,19,23]$.

We have previously reported on the establishment of new human bladder cancer cell lines from our laboratory [12]. The availability of these cell lines presented an opportunity to evaluate the prevalence and degree (titer) of antibody production by patients to their own bladder cancer cell lines (autologous reactivity). An understanding of au-

\footnotetext{
* This investigation was supported by PHS Grant number CA36933, awarded by the National Cancer Institute, DHHS. Offprint requests to: $\mathrm{H}$. Barton Grossman, University of Michigan Medical Center, 1500 E. Medical Center Drive, Box 0330, Room 2916, Ann Arbor, Michigan 48109, USA
}

tologous reactivity to bladder cancer is of practical importance because it facilitates the rational selection of potential strategies for producing human monoclonal antibodies to bladder tumor-associated antigens.

\section{Materials and methods}

The following cell lines have been previously reported: UM-UC-1, UM-UC-2, UM-UC-3, UM-UC-6, UM-UC-7, UM-UC-8, and MELBA [10, 12]. UM-UC-9, UM-UC-10, UM-UC-11, UM-UC-12, UM-UC-13, and UM-UC-14 are new human bladder carcinoma cell lines which have been established in our laboratory. A summary of the characteristics of these cell lines is listed in Table 1. The cell lines were maintained in Eagle's minimum essential medium supplemented with $1 \%$ nonessential amino acids, $2 \mathrm{~m} M$ L-glutamine, $100 \mathrm{u} / \mathrm{ml}$ penicillin, $100 \mu \mathrm{g} / \mathrm{ml}$ streptomycin, and $10 \%$ fetal bovine serum (FBS). Autologous serum from patients bearing the tumors from which these cell lines were established was obtained by venipuncture. The patient's tumor stage at the time of the blood collection varied widely: 3 patients had no evidence of disease; 5 had advanced localized diseases; 4 had lymphatic metastases; and 1 had distant metastases. The serum was obtained by refrigerated centrifugation, divided into aliquots, and stored at $-70^{\circ} \mathrm{C}$ until used. Serologic assays were performed at several different passages of the autologous cells.

Table 1. New bladder (urothelial) cell lines

\begin{tabular}{llrl}
\hline Cell line & Histology & $\begin{array}{c}\text { Highest } \\
\text { passage }\end{array}$ & $\begin{array}{l}\text { Growth in } \\
\text { nude mouse }\end{array}$ \\
\hline UM-UC-1 & Transitional cell carcinoma & 92 & Yes \\
UM-UC-2 & Transitional cell carcinoma & 202 & Yes \\
UM-UC-3 & Transitional cell carcinoma & 181 & Yes \\
UM-UC-6 & Transitional cell carcinoma & 111 & Yes \\
UM-UC-7 & Transitional cell carcinoma & 88 & Yes \\
UM-UC-8 & Transitional cell carcinoma & 20 & No \\
UM-UC-9 & Transitional cell carcinoma & 95 & Yes \\
UM-UC-10 & Transitional cell carcinoma & 92 & Yes \\
UM-UC-11 & Transitional cell carcinoma & 64 & No \\
UM-UC-12 & Transitional cell carcinoma & 53 & Yes \\
UM-UC-13 & Transitional cell carcinoma & 62 & Yes \\
UM-UC-14 & Transitional cell carcinoma & 56 & Yes \\
MELBA & Melanoma & 90 & Yes \\
\hline
\end{tabular}


Table 2. Autologous typing of bladder carcinomas

\begin{tabular}{|c|c|c|c|c|c|c|c|c|}
\hline \multirow[t]{2}{*}{ Cell line } & \multicolumn{4}{|c|}{ Immune adherence assay ${ }^{a}$} & \multicolumn{4}{|c|}{ Protein A assaya } \\
\hline & $0-10$ & $11-20$ & $21-30$ & $>30$ & $0-10$ & $11-20$ & $21-30$ & $>30$ \\
\hline UM-UC-1 & 1 & & 1 & & 1 & & 2 & \\
\hline UM-UC-2 & & & 0 & 0 & 2 & & 2 & 0 \\
\hline UM-UC-3 & 0 & 0 & & 0 & 128 & 128 & 2 & 0 \\
\hline UM-UC-6 & 0 & & & 0 & 0 & & & 0 \\
\hline UM-UC-7 & & 0 & & 0 & & 0 & & 0 \\
\hline UM-UC-8 & 0 & & & & 1 & & & \\
\hline UM-UC-9 & & & 2 & & & & 0 & \\
\hline UM-UC-10 & & 0 & & 0 & & 0 & & 2 \\
\hline UM-UC-11 & & & 0 & & & & 0 & \\
\hline UM-UC-12 & & & & 0 & & & & 0 \\
\hline UM-UC-13 & & & & 0 & & & & 0 \\
\hline UM-UC-14 & & & & 0 & & & & 0 \\
\hline MELBA & & 0 & & 0 & & 0 & & 0 \\
\hline
\end{tabular}

a Reciprocal of titer by passage number

0 signifies no reactivity with undiluted serum

Table 3. Summary of autologous typing of bladder carcinomas

\begin{tabular}{|c|c|c|c|c|}
\hline \multirow[t]{2}{*}{ Cell line } & \multicolumn{2}{|c|}{ Immune adherence assay } & \multicolumn{2}{|c|}{ Protein A assay } \\
\hline & $\begin{array}{l}\text { Low } \\
\text { passage }^{\text {a }}\end{array}$ & $\begin{array}{l}\text { High } \\
\text { passage }^{b}\end{array}$ & $\begin{array}{l}\text { Low } \\
\text { passage }\end{array}$ & $\begin{array}{l}\text { High } \\
\text { passage }\end{array}$ \\
\hline UM-UC-1 & 1 & 1 & 1 & 2 \\
\hline UM-UC-2 & NT & 0 & 2 & 0 \\
\hline UM-UC-3 & 0 & 0 & 128 & 0 \\
\hline UM-UC-6" & 0 & 0 & 0 & 0 \\
\hline UM-UC-7 & 0 & 0 & 0 & 0 \\
\hline UM-UC-8 & 0 & NT & 1 & NT \\
\hline UM-UC-9 & NT & 2 & NT & 0 \\
\hline UM-UC-10 & 0 & 0 & 0 & 2 \\
\hline UM-UC-11 & NT & 0 & NT & 0 \\
\hline UM-UC-12 & NT & 0 & NT & 0 \\
\hline UM-UC-13 & NT & 0 & NT & 0 \\
\hline UM-UC-14 & NT & 0 & NT & 0 \\
\hline MELBA & 0 & 0 & 0 & 0 \\
\hline
\end{tabular}

NT $=$ Not tested

$0=$ Signifies no reactivity with undiluted serum

a passage 20 or earlier

${ }^{b}$ passage 21 or later

The assays used for the analysis were the immune adherence (IA) assay and the protein A (PA) assay, and were performed as previously described [11]. In brief, autologous target cells were trypsinized, washed, and plated into microtest plates at a concentration of 200 cells/well $(10 \mu \mathrm{l})$. Phosphate-buffered saline with $5 \%$ gamma globulin-free FBS (PBS) was used for diluting the antibody and washing the plates. On the day of the assay, the microtiter wells containing target cells were washed and incubated with $10 \mu 1$ of serially diluted antibody or control (PBS). In the IA assay, the plates were incubated at $4^{\circ} \mathrm{C}$ for $1 \mathrm{~h}$, washed, and incubated with indicator cells $(0.5 \%$ human 0 erythrocytes with diluted guinea pig serum as a source of complement) for $30 \mathrm{~min}$ at $37^{\circ} \mathrm{C}$. In the PA assay, the antibody incubation was performed at room temperature, and the indicator cells (human 0 erythrocytes coupled to staphylococcal protein A using chromium chloride) were incubated for $\mathbf{4 5} \mathrm{min}$ at room temperature. In both assays, the plates were again washed after the indicator cell incu- bation, and positive reactions (rosettes of erythrocytes around the target cells) were determined microscopically. Results were expressed as the percentage of positive cells in each well.

Positive controls included rabbit anti-beta-2-microglobulin for the PA assay and human anti-A and anti-B blood typing sera for the IA assay. With few exceptions, replicate assays were performed on the same or different days. A positive titer was defined as the highest dilution having $20 \%$ positive cells per well.

\section{Results}

The autologous reactivity by passage and assay methods is listed in Table 2. There was little variability between assays for target cells of the same passage number whether tested on the same or different days. Four assay pairs (repeat assays using the same passage number target cell) differed by one doubling dilution, two assay pairs differed by two doubling dilutions, and only one series of assays (three tests of the same passage number target cell) differed by more than two doubling dilutions.

Autologous reactivity was found in 6 of the 13 cell lines tested. However, the titer was usually low regardless of the passage number. There was no correlation between tumor stage and autologous reactivity. Seven cell lines were tested both at low and high (greater than 20) passages (Table 3). Only one of these demonstrated a large change in autologous reactivity (greater than 2 doubling dilutions) over time. Autologous serum to UM-UC-3 target cells produced titers of $1 / 128$ in the PA assay at passages 10 and 11. At passages 21,22 , and 40 , the titer was only $1 / 2$. There was no autologous reactivity at passage 64 . The remainder of the cell lines showed little or no change with passage in vitro. Two of the cell lines were tested at very low passage numbers ( 3 or earlier). UM-UC-2 was tested at passage 1 with the PA assay. UM-UC-3 was tested at passage 3 with the IA assay. Autologous targets tested at very early passage number did not demonstrate significant changes in antibody titer with extended time in culture.

\section{Discussion}

Some individuals with cancer demonstrate an immune response to their own neoplasms by generating antibodies 
that have high specificity for their tumor [22]. Because serum contains multiple antibodies with different specificities, the detection of antibodies to tumor-associated antigens can be facilitated by employing autologous tumor cells as targets. The use of autologous tumor cell targets eliminates potential errors from antibody binding to nontumor-associated alloantigens. Employing such a strategy, tumor-associated antibodies have been detected in patients with melanoma, leukemia, sarcomas, and cancer of the brain, breast, kidney, and ovary $[3,8,16,17,20,25,27]$. The existence of autologous reactivity to tumor-associated antigens has relevance to the development of appropriate strategies for the application of monoclonal antibody technology to human lymphocytes. For example, if lymphocytes producing antibodies to tumor-associated antigens were both common and abundant, then peripheral blood lymphocytes could be randomly obtained from patients with cancer and be used to produce human monoclonal antibodies to tumor-associated antigens. On the other hand, should peripheral blood lymphocytes not be an efficient source of cells producing antibody to tumor-associated antigens, then a more productive strategy would be to utilize a lymphocyte selection process and/or immunization (in vitro or in vivo) to increase the number of lymphocytes producing antibody to tumor-associated antigens. Human monoclonal antibodies have potential advantages over murine monoclonal antibodies because of the documented antigenicity of murine antibodies in man [24].

We evaluated autologous reactivity using cell lines derived from an individual's own tumor as targets. Two sensitive assays were employed to determine antibody binding to cell surface antigens on the tumor targets at varying passage numbers. Autologous reactivity was found in 6 of the 13 cell lines tested. However, the titer was usually low. The degree of antibody binding was similar using both low and high passage cells as targets. Although clonal selection is always a potential problem when employing cell lines instead of fresh tumor, the consistency in the degree of autologous reactivity using low and high passage target cells suggests that the quantity and quality of the observed reactivity cannot simply be attributed to an artifact of tissue culture.

Our incidence of autologous reactivity in the 12 patients with urothelial tumors was $50 \%$. The serum from an additional person with melanoma of the bladder demonstrated no autologous reactivity. This incidence of autologous reactivity is similar to that reported in people with other types of malignant tumors: leukemia (14\%) [8], glioma (50\%) [5], ductal breast carcinoma (55\%) [25], squamous cell carcinoma (56\%) [4], melanoma (56\%) [26], astrocytoma (100\%) [20], and renal carcinoma (100\%) [27]. The varying incidence of autologous reactivity in these reports may not only reflect different degrees of antigenicity of these histologically diverse tumor types but also the sensitivity of the numerous assays employed. Although all autologous reactivity is by definition tumor-associated, not all autologous reactivity is tumor-specific [20]. The determination of specificity requires high titer antibody that may be further analyzed by serologic absorption and other techniques $[20$, 22]. The low antibody titers that we observed precluded further characterization of the specificity (range of reactivity) of the binding by serologic absorption. Our finding of a moderate to high frequency of autologous tumor-associated antibodies with low titer has been a recurring obser- vation in the tumor systems that have been evaluated. Furthermore, when rigorous absorption studies have been performed, many of these antibodies bind to antigens that are widely distributed through both normal and neoplastic cell populations.

A variety of sensitive assays have detected a high incidence of autologous antibody in people with diverse malignancies. However, the underlying immune response appears to be weak (antibodies of low titer) and nonspecific (not tumor-restricted) in most patients. These findings suggest that the routine use of peripheral lymphocytes from tumor-bearing patients is not an efficient strategy for the production of human monoclonal antibodies to tumor-associated antigens. Alternative strategies with documented efficacy include lymphocyte selection (lymphocytes from regional lymph nodes) [15] and immunization (both in vitro and in vivo) prior to fusion $[13,14]$.

\section{References}

1. Bander NH (1987) Monoclonal antibodies: state of the art. J Urol 137: 603

2. Bubenik J, Perlmann P, Helmstein K, Moberger G (1970) Cellular and humoral immune responses to human urinary bladder carcinomas. Int J Cancer 5: 310

3. Carey TE, Takahashi T, Resnick LA, Oettgen HF, Old LJ (1976) Cell surface antigens of human malignant melanoma: mixed hemadsorption assays for humoral immunity to cultured autologous melanoma cells. Proc Natl Acad Sci USA 73: 3278

4. Carey TE, Kimmel KA, Schwartz DR, Richter DE, Baker SR, Krause CJ (1983) Antibodies to human squamous cell carcinoma. Otolaryngol Head Neck Surg 91: 482

5. Coakham HB, Kornblith PL, Quindlen EA, Pollock LA, Wood WC, Hartnett LC (1980) Autologous humoral response to human gliomas and analysis of certain cell surface antigens: in vitro study with the use of microcytotoxicity and immune adherence assays. J Natl Cancer Inst 4: 223

6. Colcher D, Hand PH, Nuti M, Scholm J (1981) A spectrum of monoclonal antibodies reactive with human mammary tumor cells. Proc Natl Acad Sci USA 78: 3199

7. Dippold WG, Lloyd KO, Li LTC, Ikeda H, Oettgen HF, Old LJ (1980) Cell surface antigens of human malignant melanoma: definition of six antigenic systems with mouse monoclonal antibodies. Proc Natl Acad Sci USA 77: 6114

8. Garrett TJ, Takahashi T, Clarkson BD, Old LJ (1977) Detection of antibody to autologous human leukemia cells by immune adherence assays. Proc Natl Acad Sci USA 74: 4587

9. Grossman HB (1982) Natural antibody to a human bladder carcinoma cell line. Cancer Immunol Immunother 13: 89

10. Grossman HB, Wedemeyer G, Ren L (1984) UM-UC-1 and UM-UC-2: characterization of two new human transitional cell carcinoma lines. J Urol 132: 834

11. Grossman HB, Wedemeyer G, Ren L, Carey TE (1984) UMSCP-1, a new human cell line derived from a prostatic squamous cell carcinoma. Cancer Res 44: 4111

12. Grossman HB, Wedemeyer G, Ren L, Wilson GN, Cox B (1986) Improved growth of human urothelial carcinoma cell cultures. J Urol 136: 953

13. Haspel MV, McCabe RP, Pomato N, Janesch NJ, Knowlton JV, Peters LC, Hoover HC, Hanna Jr MG (1985) Generation of tumor cell-reactive human monoclonal antibodies using peripheral blood lymphocytes from actively immunized colorectal carcinoma patients. Cancer Res 45: 3951

14. Huth JF, Saxton RE, Morton DL, Irie RF (1987) A human monoclonal antibody produced by in vitro sensitization of human lymphocytes with an antigen from urine of a sarcoma patient. J Surg Res 42: 591 
15. Imam A, Drushella MM, Taylor CR, Tokes ZA (1985) Generation and immunohistological characterization of human monoclonal antibodies to mammary carcinoma cells. Cancer Res 45: 263

16. Irie K, Irie RF, Morton DL (1975) Detection of antibody and complement complexed in vivo on membranes of human cancer cells by mixed hemadsorption techniques. Cancer Res 35 : 1244

17. Kutteh WH, Doellgast GJ (1986) Autologous antibodies eluted from membrane fragments in human ovarian epithelial neoplastic effusions. II. Tissue specificity and reactivity. JNCI 76: 797

18. Mazauric T, Mitchell KF, Letchworth III GJ, Koprowski H, Steplewski Z (1982) Monoclonal antibody-defined human lung cell surface protein antigens. Cancer Res 42: 150

19. Moon TD, Vessela RL, Palme DF, Nowak JA, Lange PH (1985) A highly restricted antigen for renal cell carcinoma defined by a monoclonal antibody. Hybridoma 4: 163

20. Pfreundschuh M, Shiku H, Takahashi T, Ueda R, Ransohoff J, Oettgen HF, Old LJ (1978) Serological analysis of cell surface antigens of malignant human brain tumors. Proc Natl Acad Sci USA 75: 5122

21. Ramsey EW, Malcolm AJ (1981) The leukocyte adherence inhibition assay as a measure of antitumor immunity in bladder cancer patients. J Urol 126: 600
22. Real FX, Mattes MJ, Houghton AN, Oettgen HF, Lloyd KO, Old LJ (1984) Class I (unique) tumor antigens of human melanoma. Identification of a 90,000 dalton cell surface glycoprotein by autologous antibody. J Exp Med 160: 1219

23. Ritz J, Pesando JM, Notis-McConarty J, Lazarus J, Schlossman SF (1980) A monoclonal antibody to human acute lymphoblastic leukemia antigen. Nature 283: 583

24. Schroff RW, Foon KA, Beatty SM, Oldham RK, Morgan AC Jr (1985) Human anti-murine immunoglobulin responses in patients receiving monoclonal antibody therapy. Cancer Res 45: 879

25. Sheikh KM, Quismorio FP, Friou GJ, Lee YT (1979) Ductular carcinoma of the breast: serum antibodies to tumorassociated antigens. Cancer 44: 2083

26. Shiku H, Takahashi T, Oettgen HF, Old LJ (1976) Cell surface antigens of human malignant melanoma. II. Serological typing with immune adherence assays and definition of two new surface antigens. J Exp Med 144: 873

27. Ueda R, Shiku H, Pfreundschuh M, Takahashi T, Li LTC, Whitmore WF, Oettgen HF, Old LJ (1979) Cell surface antigens of human renal cancer defined by autologous typing. $J$ Exp Med 50: 564

Received July 23, 1987/Accepted January 19, 1988 